\title{
Characteristics of Pigs Farming System in The Bruyadori District Biak Numfor Regency
}

\author{
Antomina Estefina Koibur ${ }^{1}$, Denny A. Iyai ${ }^{1}$, John A. Palulungan ${ }^{1}$ \\ Livestock Production Laboratory, Faculty of Animal Husbandry, Universitas Papua \\ Jl. Gunung Salju Manokwari 98314, Papua Barat Indonesia \\ * Corresponding author : J.palulungan@ unipa.ac.id
}

\begin{abstract}
Bruyadori District Biak Numfor Regency is one of areas that supply pigs to several regions in Papua. One of the regions supplied is Nabire Regency. Pigs have a high economic value in Papuan society, because pigs can be used as savings, are very useful in customs events in Papua (paying fines, dowry) and demand for pork increases at ecclesiastical events (Christmas and Easter). This research is expected to provide an overview of the characteristics of pig farming systems in Bruyadori District, Biak Numfor District. The research method used is descriptive research method with case study techniques, the case in this study was farmers. There were 30 respondents who were taken to get data. Pig farmers in Bruyadori District are $100 \%$ Biak or Papuan indigenous tribes, and judging from their education background, it is still very low mostly only have elementary and junior high school diploma but the experience of breeding is very good, about 20 - 40 years, whereas the purpose of raising livestock as a side business, farmers have a main job as farmers and fishermen so the number of livestock ownership is still less than 1-5 pigs because the number of livestock is influenced by the number of litter size and farowing rate which is very low every year, about 1-5 pigs and the number of sow that is productive is only 1 sow. Farmers in the Bruyadori District provide feed still from the garden and household waste or food scraps from the kitchen. The maintenance system applied is an extensive and intensive maintenance system.
\end{abstract}

Keywords: Bruyadori District, Biak Tribe, Pigs, Maintenance System

\section{Introduction}

Pig farms are one of the livestock commodities that have potential market opportunities to be developed as agribusiness ventures in the future. In some areas in Indonesia, such as East Nusa Tenggara Province, Bali, North Sumatra, South Sulawesi, Papua, West Kalimantan, North Sulawesi, Bangka Belitung, and Central Sulawesi, pigs have economic and socio-cultural values (Gobay, 2011), where cultivation Pig livestock cultivation is a household-scale economic activity carried out from generation to generation according to local preferences and customs. Pig farming business is a business that has been existed for a long time.

There is an increase in Development of Pig Population in Indonesia of 1.7\%, from 7.9 million in 2012 to be 8.1 million of pigs (from 2012 - 2016) in 2016. While from the aspect of production increase, it increased 9.6\%, from 232.143 tons in 2012 to 342.346 tons in 2016 (Directorate General of Animal Husbandry and Health Production Development, 2003). Pigs are the most numerous cattle on Numfor Island, especially in 
the Bruyadori District. The majority of the community cultivated pigs as a main business or a side business. This is driven by the increased demand for livestock or pork as well as meeting household needs, namely to funding family members who are continuing school, as well as for funding social and customs needs such as fines, dowry or wedding asset in other events (Gobay, 2011). In Papua, it is clear that the request is near ecclesiastical and other social days such as Christmas, Easter and New Year.

Numfor is one of the pig stock point areas for Biak, Serui, Nabire, and Manokwari areas (Iyai, 2008). This area also includes areas that sell pigs to the regions and other islands in Papua for that good maintenance will give good results. But so far there has been no research conducted on the patterns or systems on pigs farming in Bruyadori District, Biak Numfor District. It is expected that this research is expected to provide an overview of the characteristics of pig raising systems in Bruyadori District, Biak Numfor District.

\section{Materials and Methods}

This research was conducted in Bruyadori District, Biak Numfor District, the duration of the study was approximately 3 months. The research method used is descriptive research method with case study technique, the case in this study was farmers. There were 30 respondents who were taken.

Data collection method used is a structured interview method using a list of questions (questionnaire). The data collected consists of primary and secondary data. Primary data were obtained from a list of questions by direct interviews with farmers and direct observations at the study site. While secondary data is obtained through literature, and the Livestock Service Office of Biak Numfor Regency. Variables observed were characteristics of farmers, characteristics of pigs and feed characteristics. Data obtained from the results of the interviews are tabulated and presented in tabular form.

\section{Results and Discussion}

\section{Characteristics of Farmers}

The characteristics of pig farmers in Bruyadori District were observed in seven aspects, namely age, ethnicity, education, purpose of farming, occupation of farmers, experience of farming, and the number of livestock owned.

Age. Age of farmers in the Bruyadori District are grouped into three age groups to be $25-45$ at $50 \%$, age $46-65$ at $35 \%$ and over 65 years at $15 \%$ Age of farmers in Bruyadori District is relatively dominant ranging from 25-45 years old with the number of farmers 15 households (50\%) followed by ages 46-65 years as many as 13 households $(35 \%)$ and aged $>65$ years as many as 2 households $(15 \%)$. According to Nasaruddin (1995), the age range of 15 - 65 is still classified as a productive age group as long as the farmer still has a good physical and mental for business. For this reason, a good and productive age will guarantee farmers' activities to be good because it is supported by them being physically and mentally healthy. 
Tribe. The tribe at the research site that farm pigs is a native tribe of Papua. $100 \%$ of the farmers in the Bruyadori District are Biak, this is because the area is inhabited by many people from the Biak tribe. According to observations at the time of the study there were no other ethnic Papuans living and residing in the area thus indicating that this area had relatively little interaction with other regions and was relatively isolated from outside communities.

Education. The level of education of farmers in the District of Bruyadori Elementary Education is 27\%, Middle School 40\%, High School / Vocational School / SPG 23\%, Higher Education 7\% and no school diploma by 3\%. The level of those with junior high school diploma is more dominant, with 12 families $(40 \%)$, followed by those with elementary and senior high schools diploma, each ranging between $27 \%$ and $23 \%$. The lowest level of education is PT and farmers who never attended school, respectively $3 \%$ and $7 \%$. The most dominant farmers in the Bruyadori District with a junior high school background education of 12 households (40\%). According to Prawiro (1981), the level of education is very influential in the success of a livestock business, because education supports the process of absorbing information sourced from the mass media, electronic media and training that can be obtained by farmers, especially in information about how to maintain a good pig farming system.

Farming experience. The experience of animal farming is the experience and knowledge that farmers have in doing business of farming pigs for less than 20 years by $90 \%, 20-40$ years by $7 \%$ and more than 40 years by 3\%. Experience is good knowledge. People who are experienced in their field have better working skills than people who just started. According to Elaine, (2007) through work experience there has been a process of increasing one's knowledge.

Farmer's jobs. Farmers earn monthly wage by doing daily work. Farmers' occupations in the Bruyadori District include private sector (farmers and fishermen) is at $83 \%$, village officials at $10 \%$, and Honorary (Non PNS-Civil Workers) at $7 \%$. This is in accordance with Basna (2011), that $92 \%$ of North Ayamaru pig farmers' livelihoods are farmers. The main occupation of farmers can directly affect the pig raising system that is carried out because there is a tendency for farmers to pay more attention to their main job so that that they can not pay full attention to providing maintenance for pig farming.

Breeding Goals. The purpose of farmers in doing the business of farming pigs as a side business is as much as $93 \%$ and those in the business for their main job is $7 \%$. The result of field observations shows that the majority of people have jobs as farmers and fishermen and as a main business that is $7 \%$ as a source of income for families. This means that the purpose of farming pigs as a side business, in addition to being sold, is to be consumed and as a means to pay for dowry and for traditional customs (Kinho, 2017 and Gobay 2011). Meanwhile, as the main business is to sell products to meet the household needs.

Number of pigs owned. The number of pigs owned in the Bruyadori District is $83 \%(25 \mathrm{HH})$ of farmers having 1-5 pigs, and 10\% (3 HH) of farmers have 6-15 pigs and $7 \%(2 \mathrm{HH})$ of farmers have pigs $>15$ pigs. Farmers in the Bruyadori District have the most pigs, at 1-5 pigs because there are new farmers. 


\section{Characteristics of Pigs as Livestock}

Characteristics of pigs in the Bruyadori District during the time of the study covered 12 aspects, namely origin of seedlings, type of seedlings, litter size, forrowing rate, mating system, pig age, maintenance system, early age, BCS, weaning age, sow's nursery age, mortality, survival rate.

Ways to get the piglets. Piglets in the Bruyadori District come from 3 ways, namely from purchasing, receiving donation, or from gifts. The number of farmers receiving pigs by buying more livestock is $60 \%$ (18 households) and receiving donation only $40 \%$ (12 households) while there is no assistance from government agencies. According to Basna (2011) that the majority of farmers in the North Ayamaru District get piglets by purchasing them is at $52 \%$. This means that livestock are received and taken care of by the community through self-help by community itself while there support or donation by the local government

Farmers who buy pigs outnumbered those who get the piglets from other people, namely relatives or neighbors. According to interviews with informants that the pigs purchased were piglets and grower pigs while the giving was only for pigs aged 1-3 months after and before weaning. The reason given by farmers is because if they wait until the pigs reach maturity, it will be a loss for those who are giving them away as these pigs have been raised and fed for many years

Different breeds of livestock. Different breeds of pigs, namely pigs raised by farmers in the Bruyadori District, $100 \%$ farmers raise local pigs. According to interviews that farmers can only raise local pigs because this breed of pig can be easily gotten in this area and they are easy to raise. According to farmers raising pigs that are not of local (breed) means that they have to pay money and the pigs are gotten outside District. According to Sihombing (1997), local pigs are considered easy to consume various types of feed with seeds, tubers, have a high resistance to the environment ranging from moderate to extreme environment and the cattle are easy to take care of, local Papuan farmers prefer local pigs rather than pig herds (VDL) because local pigs are easy to take care of, get feed for, and pigs can survive in an unfavorable environment (Maryen, 2007)

Litter size (piglets/births). Litter size is the number of births per year. $20 \%$ of pig farmers in Bruyadori District have 1-5 piglets, and 10\% can breed between 5 - 9 piglets and $10 \%$ more piglets are $>10$ births while $60 \%$ are absent from farmers new farmers of pigs, there are gilts that have not been mated, there are also farmers who only raise boars. Kinho (2017) states that 20\% of farmers in SP 3 and SP 4 in Prafi District have litter sizes of 1-5 pigs per year. The results of interviews that one of the obstacles that affect the high and low litter size is the factor of mating techniques because farmers rarely raise boars so that the gilts will be released if they show signs of heat.

Farrowing rate. Farrowing rate is the number of sow herd's reproductive performance in a year in the Bruyadori District. $60 \%$ of farmers do not have sow herds in a year, $27 \%$ of farmers have 1 reproductive sow in a year, $10 \%$ of farmers have reproductive sow in a year and 3\% of farmers have 3 reproductive in a year. Normally, the frequency of pig breeding in the Bruyadori District is only experienced by $10 \%$ of farmers, while the majority of them only experience 1 frequency per year. This is an indication that the weak system of pig farming by the Biak community. 
Mating system. Pig breeding system by farmers in the Bruyadori District. 53\% of farmers do not have a pig farm where the breeding occurs, while $47 \%$ of farmers in the Bruyadori District do a natural breeding system but there is a process of breeding of swine by humans. Because pigs that are kept are released together - male and female, so there is a natural breeding. In addition, there are also gilts who are released to look for boars themselves. According Sasroamidjojo (1975), that the natural mating system occurs when a boar with several gilts are placed in one cage so that a mating will occur.

Age of pigs. The age of pigs in the large Bruyadori District is $57 \%$ piglets with farmers from 17 households. This states that related to the number of pigs in the Bruyadori District, $33 \%$ of farmers raise pigs with the total farmers is 10 families, while families that have teenage pigs with the percentage of $10 \%$ with the total farmers is 3 families. According to the results of interviews with farmers that many young pigs aged 8-12 months but have mated before that starte breeding at the age of one year old do not count as teenage pigs.

BCS (Body Condition Score). Body Condition Score (BCS) is an assessment technique that helps farmers assess the level of body fat in a sow in the Bruyadori District at the time of the study. The scoring ranges from 1-5 (1 very thin, 2 thin, 3 moderate, 4 fat, 5 very fat). There are many pig herds in Bruyadori District with the BCS of 3 which means not too fat but not too thin either at $73 \%$ with the total number of $22 \mathrm{HHs}$, and BCS number 2 and four $17 \%$ and $10 \%$ ie $17 \%$ have the number of farmers $5 \mathrm{HH}$ and $10 \%$ the number of farmers has 3 families while BCS one (1) and five (5) is not counted because in the Bruyadori District there are no very thin and very fat pigs. It can be said that the dominant pig in the study area has a value of BCS 3 (moderate). According to Degei (2017) Body condition score obtained from the study of the body condition score of the Paniai Regency pigs is a score of 3 (ideal) $44 \%$ with the characteristic of a smooth palpable protrusion on the ribs, spine, lumbar bone and coccyx.

Weaning age of sow. Weaning age of sow (weaning age / weanefs) in Bruyadori District ranges from 1-6 months is at 23\% of weaning cattle are 3 months old with the number of 7 households, $13 \%$ of weaning animals are 4-6 months old with the number 4 $\mathrm{HH}$ farmers and $7 \%$ of farmers who remove pig weaning in 1-2 months with the number of $2 \mathrm{HH}$ farmers while $57 \%$ are the number of farmers who do not have weaning piglets with $17 \mathrm{HH}$ farmers.

Pig farming system. On The pig farming system in the Bruyadori district $24 \mathrm{HH}$ $(80 \%)$, it was found out that $24 \mathrm{HH}(80 \%)$ of farmers raising pigs intensively, which means, pigs kept in cages for all and the feeding and the drinking are carried out by the farmers. The semi-intensive system is not practiced by farmers in the Bruyadori District. About $6 \mathrm{HH}(20 \%)$ of farmers raise livestock by allowing cattle outside the cage and drinking cages to be given by the farmers at a certain amount of time, the percentage is intensive in the maintenance system because the farmers provide pens to keep pigs. Intensive maintenance of this system is conducted where the factors that play a role in increasing the productivity and reproduction of pigs that are kept such as feed, breeding and management factors in this system are considered by farmers (Wiliamson, et al, 1993).

The early age of pig mating. Early age is the initial age of pigs mated in Bruyadori District. There are 4 farmers mate pigs when the pigs are 8-10 months (13\%), 
7 farmers (23\%) mate pigs at 1 year old of age and 1 farmer (3\%) mate livestock at the age of $>1$ year. The results of interviews with 18 farmers in the Bruyadori District did not mate livestock because their livestock were still in the piglet phase and were also not ready to be mated, there are also gilts that are ready to be mated but there are no boars that are ready for breeding nearby. There are also farmers who keep only male pigs. (Aritonang, 1993) states that pigs can be mated at the age of the third estrus, that is at the age of 8 months so that the pigs breed at the age of 1 year.

Mortality. Mortality is the number of pigs that died in the District. The total mortality of pigs ranged from 1 to 4 pigs namely $3 \mathrm{HH}(10 \%)$ had 1 dead pig and $1 \mathrm{HH}$ (3\%) which had 2 dead pigs and also $3 \mathrm{HH}(10 \%)$ who have 3 dead pigs are followed by $1 \mathrm{HH}(3 \%)$ who have 4 dead pigs while $22 \mathrm{HH}(73 \%)$ in the Bruyadori District of pigs do not experience high mortality. This shows that farmers are able to raise livestock well.

Survival rate. Survival rate is the number of pigs living in the Bruyadori District is around $83 \%$ (25 HHs) owning living livestock with 1-5 pigs (both teenage and adult pigs) and $10 \%$ (3 HHs) have a number of living cattle of 6-10 pigs, while farmers who have pigs $<20 \%, 7 \%$ ( 2 households). This shows that $83 \%$ of farmers in the Bruyadori District have the most living pigs, so it can be said that the survival rate in the study area must still be increased by reducing the mortality rate.

\section{Feed Characteristics}

Feed characteristics include 4 aspects, namely the source of feed, the feeding frequency, feed processing, and the trough used by farmers in Bruyadori District.

Feed source. As for pig feed sources in the Bruyadori District, 50\% of farmers (15 households) use household waste as a source of food and 50\% of farmers (15 households) use agricultural produce as a source of feed. This states that the source of pig food is still very simple, namely from household waste by using leftovers from the kitchen so that it affects the nutritional needs and nutritional value of the meat the pigs produce. According to Aritonang (1995), farmers in Indonesia still provide pig feed in a traditional way without considering nutritional needs. As quality feed can affect the productivity of these livestock. According to Blakely et al. (1992) that the supply of protein given to various classes of pigs must be considered both in quality and quantity, because each pigs' growth stage of pigs has their own nutritional needs and different ways of feeding.

Feeding frequency. The frequency of feeding pigs is the number of times a farmer feeds pigs in the Bruyadori District, and they feed the pigs ranging from 1, 2 and 3 times a day. It can be seen that $67 \%$ of farmers $(20 \mathrm{HH})$ feed pigs twice a day, with 20 $\mathrm{HH}$ and $27 \%$ of farmers feed 3 times a day ie the number of $8 \mathrm{HH}$ farmers, while $7 \%$ of farmers feed 1 time in a day with 2 households. It can be seen that farmers in the Bruyadori District mostly feed pigs twice a day. This is in accordance with Sutrisno (1997) and Iyai (2008), that most of the pig farmers in Manokwari routinely feed their animals twice a day (morning and evening). 
Feed processing method. Pig feed processing methods in the Bruyadori District, by cooking the feed first or feeding the pigs pre-cooked food with number of farmers is at $73 \%$ ( 22 Households- $\mathrm{HH}$ ), while $27 \%$ of farmers $(8 \mathrm{HH})$ provide cooked pig feed to other farmers, therefore it can be seen that farmers do not give raw feed to pigs but are given raw feed together with feed that has been cooked. Aritonang (1993) states that processing cooked feed to pigs in hopes that it will increase the level of their enjoyment, nutritional value, and easiness level in handling the pigs.

Trough. Trough is a container provided by farmers to feed pigs in the Bruyadori District. Pig trough consists of several containers, $37 \%$ of farmers use jerry cans for pig feed, $20 \%$ of farmers use pans, $18 \%$ of farmers use wood by creating a rectangular shape hole in the middle, and $7 \%$ of farmers use a board created in rectangular shape, while $3 \%$ of each farmers use large pans of large skillet, Belanga, made from cement by casting it in a rectangular shape and using a middle size pan and there is no trough. According to (Basna, 2011) that 52\% of pig farmers in the Ayamaru District use jerry cans as a place to feed pigs.

\section{Conclusion}

Farmers in Bruyadori District are 100\% Biak or Papuan indigenous tribes, and judginf from education level, it is still low with most of them only graduated from elementary or junior high school but they have a good farming experience ranging from 20-40 years of experience, while the purpose of farming livestock as a side business, farmers have a main occupation as farmers and fishermen so the number of livestock they own is still less than 1-5 pigs because the number of livestock is influenced by the number of litter size and farrowing rate every year which is very low, about 1-5 pigs and there is only 1 productive sow.

Farmers in the Bruyadori District provide feed from garden products and household waste or food scraps from the kitchen. The maintenance system applied is an extensive and intensive maintenance system.

\section{Suggestion}

Support from the local government in the form of providing counselings on animal farming, animal health and how to maintain a good livestock raising system for farmers, as farmers in the Bruyadori District have a lot of knowledge and a high willingness to farm pigs. A capital and livestock assistance to farmers is also needed.

\section{References}

Aritonang, 1993, Teknik Beternak Babi Di Indonesia. Penebar swadaya Jakarta.

Aritonang, 1995, Teknik Beternak Babi Di Indonesia. Penebar swadaya Jakarta.

Basna, A.2011. Karakteristik Mofometri Ternak Babi Persilangan (sus sp) Pada Sistem Pemeliharaan Yang di Umbar di Areal Perkebunan Kelapa Sawit dan di Kandang di Lembah Prafi Kabupaten Manokwari. Skripsi Sarjana Peternakan Fakultas Peternakan Perikanan dan ILmu Kelautan. Universitas Negeri Papua. Manokwari (Tidak Di Terbitkan). 
Blakely J, E dan Bade .D . H ,1992. Ilmu Peternakan. Gajah mada university press. Yokyakarta.

Degei N, 1017. Skor Kondisi Tubuh Babi dan Identifikasi Cacing Gastroin Testinal di Distrik Akadide Kabupaten Paniai. Srkipsi Sarjana Peternakan Fakultas Peternakan Universitas Papua.

Direktorat Jendral Bina Produksi Peternakan dan Kesehatan. 2003. Tahun 2003 Sebagai Tahun Kebangkitan Peternakan dan Kesehatan Hewan Indonesia, Pedoman Pelaksanaan Kegiatan. Jakarta.

Elaine B. Johnson. (2007). Contextual Teaching And Learning Bandung: MLC.

Gobay B. 2011, Hubungan antara motif ekonomi dan motif sosial terhadap perkembangan ternak babi masyarakat suku arfak manokwari. Laporan penelitian.Fakultas Peternakan Perikanan dan Ilmu Kelautan. Universitas negeri papua. Manokwari.

Iyai, D. A. 2008. Inovation Prossbilities In Pig System in manokwari. Papua Barat. Province Indonesia. Thesis. MSc. Wageningen University. The Netherlands.

Kinho, M. 2017. Identifikasai Sistem Pemeliharaan Ternak Babi di SP 3 dan SP 4. Distrik Prafi Kabupaten Manokwari Skripsi Sarjana Peternakan Fakultas Peternakan Universita Papua.

Maryen, 2007. Pola Pemberian Dan Jenis Pakan Yang Diberikan Pada Ternak Babi Oleh Masyarakat Di Distrik Samofa. Kabupaten Biak Numfor (Skripsi Sarjana Fakultas Peternakan Perikanan dan Ilmu Kelautan Universitas Negeri Papua Manokwari).

Nasaruddin. 1995. Pengaruh Sistem Irigasi Teknis Terhadap Perkembangan Cabang Usaha Tani Padi Sawa Di Daerah Prafi B Unit II SP VII Kecamatan Manokwari. Skripsi Sarjana Faperta Uncen. Manokwari.

Prawiro, R.H 1981. Kependudukan (Teori, Fakta dan masalah) alumni/1981 Bandung.

Sihombing, D.T.H 1997. Buku Ternak Ilmu Babi. Cetakan Pertama Gajha university Press (IKAPI). Yogyakarta.

Sosroamidjojo, 1975. Ternak Potong dan Kerja.C.V. Yasaguna. Jakarta.

Sutrisno.A.N. 1997.Pertumbuhan Anak Babi Pra Sapih dan Lepas Sapih dan Lepas Sapih Pada Ternak Babi Rakyat di Kecamatan Manokwari. Skripsi sarjana.

Williamson, B. dan W.J.A. Payne.1993. Pengantar Peternakan di Daerah Tropis. Gajah Maja. University Perss. Yogyakarta. 